RESEARCH ARTICLE

\title{
Geomorphosite Assessment at North Karangsambung -Karangbolong Geopark Kebumen, as Tools of Geotourism Development
}

\author{
Chusni Ansori ${ }^{1,2 *}$, I. Wayan Warmada ${ }^{3}$, Nugroho Imam Setiawan ${ }^{3}$, Herry Yogaswara $^{4}$ \\ ${ }^{1}$ Centre for Geotechnology, Indonesian Institute of Science, LIPI- Bandung, West Java, Indonesia, \\ ${ }^{2}$ Doctor in Geological Engineering, Department of Geological Engineering, Faculty of Engineering, Universitas Gadjah Mada, Yogyakarta, Indonesia \\ ${ }^{3}$ Department of Geological Engineering, Faculty of Engineering, Universitas Gadjah Mada, Yogyakarta, Indonesia \\ ${ }^{4}$ Research Center for Population, Indonesian Institute of Sciences, LIPI-Jakarta, Indonesia
}

* Corresponding author : chus001@lipi.go.id, ansorich.63@gmail.com

Tel.:+62-81-32663-0373

Received: Apr 23, 2021; Accepted: Sept 14, 2021

DOI: $10.25299 /$ jgeet.2021.6.3.6753

\begin{abstract}
Geopark is a sustainable regional development concept that combines geological, biological, and cultural diversities through conservation and education activities to improve the community's welfare. Kebumen Regency has a National Geopark Karangsambung-Karangbolong (GNKK) covering 543,599 Km2 with 41 geosites, 8 cultures, and 8 biosites since 2018. The northern part of the area is a geological heritage that is widely used for field geological education.

The study aims to identify and assess geosites and geomorphosite in the north area, describing the region's geomorphological processes and geological evolution. Field research was conducted to get an overview of geological diversity, geomorphology, and geosite and determine the selected geomorphosites. Those have been decided as the supporting geopark, so that their unique geological conditions must be already described. Geomorphosite assessment was done quantitatively using the Kubalikova method by assessing five main parameters that include; Intrinsic and scientific value, the value of education, economic value, conservation value, and added value.

Pentulu Indah (PI) is the best geomorphosite at north GNKK to look at the differences between pre-tertiary mélange landform with a tertiary volcanic sediment structure. Wagirsambeng is the best geomorphosite to knows about the reversal of the geological process of the anticline and synclinal ridge. The scientific and intrinsic value of $\mathrm{PI}=4$, while Wagirsambeng $=3$. The educational value of PI $=4$, while Wagirsambeng $=2$. Economic value is still not satisfactory, but PI $=2$, while Wagirsambeng $=1.5$. Conservation value of P.I. $=3.5$, while Wagirsambeng $=2.5$. Added value PI $=2.75$ while Wagirsambeng $=1.5$. Based on those, geomorphosite Pentulu Indah is 16,26 point or a good value $(87.83 \%)$ while Wagirsambeng is 10.5 point or fairly level $(56.75 \%)$
\end{abstract}

Keywords: Geopark, Karangsambung, Geomorphosite, Pentulu Indah, Wagirsambeng, Asessment.

\section{Introduction}

\subsection{Background study}

According to (UNESCO, 2016), a geopark is a protected area with extraordinary geological elements - including archaeological, ecological, and cultural values where local communities are invited to protect and improve the functioning of natural heritage. Key elements include geological diversity, biodiversity, and cultural diversity with the ultimate goal of protecting Earth's diversity (geodiversity), environmental preservation, and broader earth science education. The Global Geopark Network (GGN, 2021) defines geopark as areas with clear boundaries that enable sustainable local development, both on social, economic, cultural, and environmental aspects. The concept of regional development involves many stakeholders to provide significant regional impacts for conservation, education, and improving the surrounding community's welfare based on sustainable green tourism activities (Green Tourism). Geopark has three main pillars; geodiversity, biodiversity, and cultural diversity (Ansori, 2018), Figure 1.

Geodiversity is a geological paradigm covering the diversity of geological environments, phenomena, and active processes that make up landscapes, rocks, minerals, fossils, soils, and other deposits that provide a framework for life on
Earth (Gray, 2008). Geological diversity is unique in geological appearance (rocks, minerals, and fossils), geomorphology (landscapes and physical processes), geological processes, and soil formation (Murray Gray, 2013). Geodiversity is a neutral term that describes various abiotic phenomena on Earth. Geological diversity is the backbone of geo-heritage, geoconservation, and modern society itself (Gray, 2018).

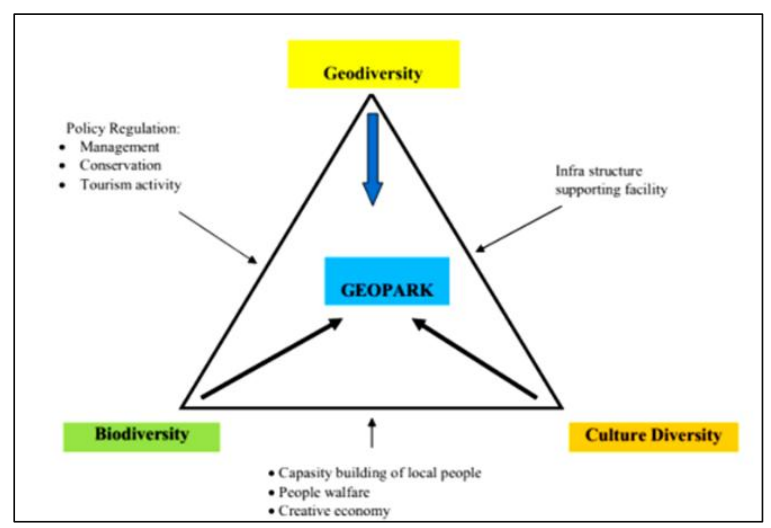

Fig 1. Geopark comprises three main pillars in geological, biological, and cultural diversity for conservation, education, and local economic development (Ansori, 2018). 
The concept of geomorphological heritage includes soil forms and processes that play a crucial role in understanding Earth's history and connect with biological and cultural heritage (Reynard and Coratza, 2016). It is widely recognized that geomorphological processes and soil forms have a fundamental role in supporting habitats, species, and ecosystem/environmental services (Gordon, J.E., Barron, 2011; M. Gray, 2013; Gordon, J.E.; Crofts, R.; Diaz-Martinez.E; and Woo, 2017). Simultaneously, geomorphological heritage includes geomorphological objects and cultural components with heritage values partly determined by the geomorphological context in which they are incorporated (Panizza, M., Piacente 2009; Gordon, 2012; Murray Gray, 2013; Reynard and Giusti, 2017). Geodiversity elements may have different values, ranging from more concrete, economic, functional, scientific, and educational, to intangibles, such as intrinsic values, culture, and aesthetic values (M. Gray, 2013). Therefore, it is necessary to assess a value that is considered outstanding. A site is held to have scientific value when research conducted directly at that location or using samples collected from it has resulted in significant scientific understanding for geosciences advancement nationally and internationally. Besides, sites relevant to the history of geosciences at the national and international level can also be considered to have a scientific value. Geological diversity with high scientific, educational, beauty, and cultural value is made as geosite or geomorphosite (Reynard, 2005) or geotope (Grandgirard, 1999). A site is held to have scientific value when research conducted directly at that location or using samples collected from it has resulted in significant scientific understanding for geosciences advancement nationally and internationally (Brilha, 2016).

Understanding Geotourism begins with an understanding of the environment. Geotourism was developed to reduce the negative impact of mass tourism with tourist attractions in the form of geomorphology and geological processes (Newsome, D. \& Dowling, 2010). The natural environment is defined as an environment that includes abiotic elements, biotic and cultural elements. Newsome, D. \& Dowling, (2010) refers to it as a component of ABC (Abiotic, Biotic, Culture). These components become a real force for geotourism development activities. A (Geodiversity/Abiotic), B (Biodiversity), C (Culturediversity) components are also the main component of the geopark, so geotourism is the main activity in geopark to drive the local economy sustainably. KarangsambungKarangbolong Geopark consists of 41 geosites, 8 biosites, and 10 cultures, for geotourism development in the northern part of the geopark needs to be assessed

The assessment of elements of geological diversity includes a scientific value (representation, integrity, persuasion, scientific understanding), educational value (didactic potential, variation of geological elements, accessibility, safety), tourism value (scenery, geological value, accessibility, safety) (Brilha, 2018). Assessment of geological diversity can use scoring and weighting models. Considers (Ansori, 2018) that the high value of geosite candidates if the geosite has a high value on three elements of diversity at once, namely geological diversity, biological and cultural diversity.

Several parameters must be met to assess a site's feasibility for tourism purposes based on this geology. Several researchers have researched geotourism by quantifying various agreed parameters. However, the authors still differ in terms of the parameters that need to be quantified. Some of these authors are (Bruschi and Cendrero, 2005), (Panizza, 2001), (Pralong, 2005), (Reynard and Coratza, 2007) (Serrano and GonzálezTrueba, 2005) (Zouros, 2005) and (Kubalíková, 2013).

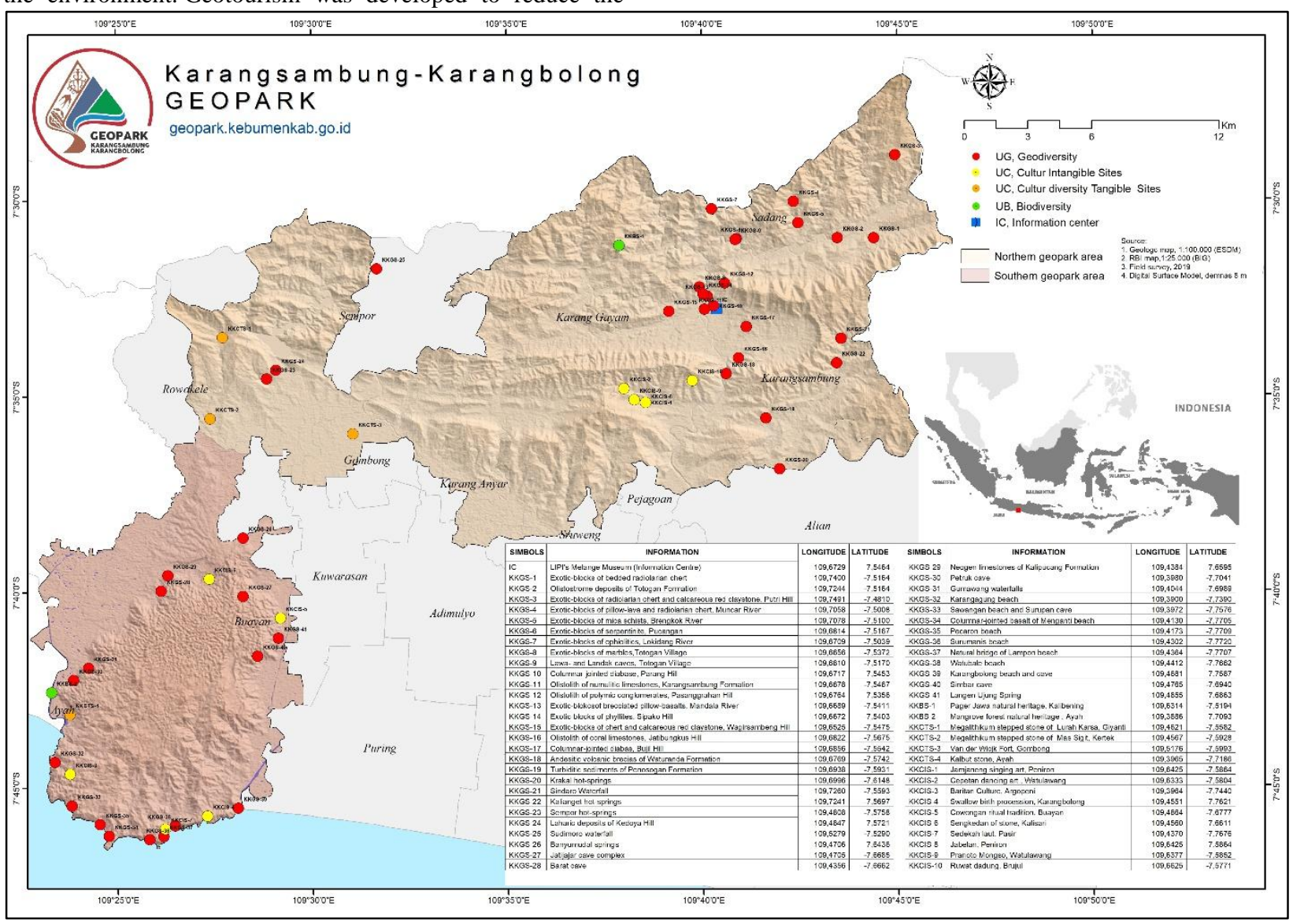

Fig 2. Research area at north area of Karangsambung-Karangbolong Geopark, Kebumen, Central Java, Indonesia 


\subsection{Research objective}

Kebumen Regency has had a National Geopark Karangsambung - Karangbolong (GNKK) in 2018, covering $543,599 \mathrm{Km} 2$ in 12 sub-districts, 117 villages consisting of 41 geosites, ten cultural sites, and eight biosites (Fig.2). The northern part of the GNKK area is a geological heritage widely used for field geology education by students from Indonesian and foreign universities since 1964. Many locations are utilized in the field of geological education as a geosite. To be able to understand and assess landscape geosite in the north, this research was carried out.

\section{Methodology}

The research was conducted through field surveys to overview geological conditions, geological diversity, geomorphological diversity, and geosite in the research area. A selection of various geomorphological and geosite diversity in the northern region of GNKK so that the landscape is obtained describes the region's geological conditions and represents the existing geosite. To clarify the diversity of selected geology, morphological photos, rock photos, and morphological sketching are carried out. The assessment of landscape geosite was selected using quantitative methods introduced by (Kubalíková, 2013). She has summarized and examined various parameters of the authors who were proposed to be quantified in evaluating the feasibility of a geosite. There are four main parameters agreed upon, namely geodiversity, geoconservation, geosite and geomorphosite. The four main parameters it is divided into five main value parameters, namely; 1 . Intrinsic and scientific values; 2. Value of Education; 3. Economic Value; 4. Conservation Value; and 5. Added Value. These five things are quantified (weighted) with values 0 (the method does not consider the criterion), 0.5 (partly considers the criterion), and 1 (considers the criterion).

\section{Result and Discussion}

\subsection{Geomorphosite}

Geomorphological heritage/landscape geosite is also often referred to as geomorphosite, (Panizza, M., Piacente, 1993), geomorphological assets (Quaranta, 1993), geomorphological goods (Carton, A., Cavallin, A. Francavilla, F., Mantovani, F., Panizza, M., Pellegrini, 1994), geomorphological sites (Hooke, 1994), geomorphological geotopes (Grandgirard, 1995), sites of geomorphological interest (Rivas, V., Rix, K., Frances and Cendrero, A., Brunsden, 1997). Geomorphological heritage includes landscapes and their genetic processes as well as their perceptions and cultural representations (Paola Coratza, 2018). Geomorphosite is also often included as a geosite, but there is also a difference of opinion that geomorphosite does not include geosite. Geological Site (Geosite) is a geological heritage in a geopark with certain characteristics, both individual and multiobject, and is an integral part of an evolutionary story of the formation of a region (Perpres, 2019). Based on field observation on 24 geosites in Karangsambung Geoheritage, it can be selected two geomorphosite namely Pentulu Indah (PI) and Wagirsambeng (Figure 3). PI geomorphosite as pra-tertiary mélange complex morphology, and Wagirsambeng as amphitheater morphology of tertiary rock.

\subsubsection{Pentulu Indah Geomorphosite}

It is a natural tourism area administratively located in Karangsambung village, Karangsambung district, Kebumen Regency. Located at an altitude of $275 \mathrm{~m}$ asl, it is about $500 \mathrm{~m}$ from the Karangsambung geological field camp. This tourist location is managed by Pokdarwis Karangsambung tourism village, presenting a stunning landscape sensation on a cool expanse of pine forest on the slopes of G. Paras. Pokdarwis (Kelompok Sadar Wisata) is the management of village tourism activity. If we are in this location in the morning, it feels like we are on a smooth white cloud. The more daylight will be seen, a red tinge of morning sunlight through the clouds against Sindoro and Sumbing mountains background (Figure 4). There will be cool air with the wind's whistle and pine leaves' subtle friction during the day to evening. The site is on a layered sandstone and andesite breccia of the Waturanda Formation. Large chunks of andesite breccia resulting from residual erosion leave uniquely attractive forms as photo spots. Currently, this tourist attraction has been equipped with a variety of tourist supporting rides. The landscape's appearance provides very useful education to understand earth dynamics in the Karangsambung area. There is a contrast between the topography in the north and the southern part of the valley, where the Luk Ulo River flows in the middle.

Looking to the east, it is clear that the valley of S. Luk Ulo separates the difference in the morphology of the rock on the left from the rock on the right in the middle. The left landscape is included in the geomorphological unit of melange S13.2 hills with steep slopes and weak erosion (Ansori et al., 2020), characterized by isolated, irregular, prismatic hills. Apparent dips are generally to the southeast, with steep slopes separated by a narrow valley around them. The slope of the rock layers to the southeast is in line with the slope of the mica-schist foliation at K. Brengkok, with a position of $\mathrm{N} 70^{\circ} \mathrm{E} / 25^{\circ}$. You can see four hills in prismatic; based on field observations, each rock hill is different. G. Gliwang (northernmost) is composed of mica schists and pelitic sediments, G. Gemantung is composed of meta graywacke sandstones, G. Paruk is composed of basalt and chert, and serpentinite in G. Clekep (southernmost), Figure 5 .

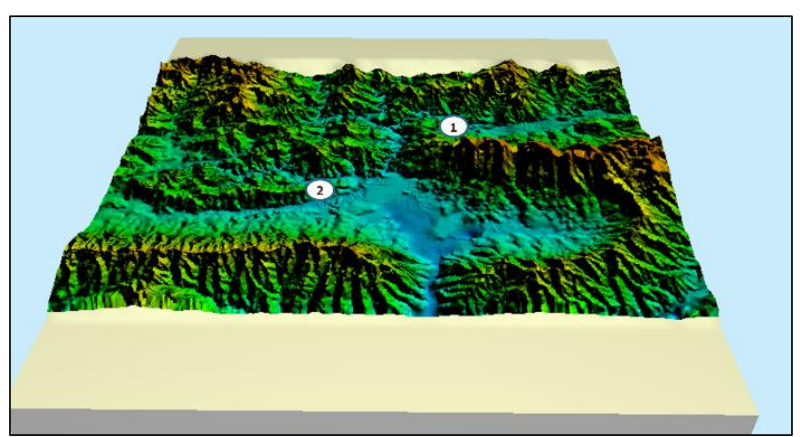

Fig 3. Geomorphosite in the northern part of geopark in the form of 1). Pentulu Indah (P.I.) and 2) Wagirsambeng Hill

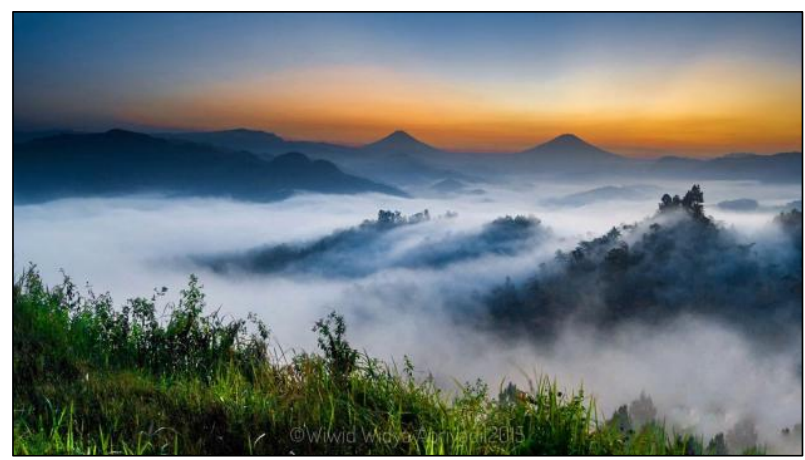

Fig 4. The scenery from Pentulu Indah (P.I.) in the morning by Wiwid Widya

$\mathrm{K}-\mathrm{Ar}$ dating of mica schist at Brengkok River resulted in the age of $117 \pm 1.1$ m.y.a (Ketner et al., 1976). K-Ar dating on mica schist rocks obtained $101 \pm 5.09$ million years, $103.05 \pm$ 5.15 million years (Suparka, 1988), and $115 \pm 6$ million years 
(Miyazaki et al., 1998). The dating of high-pressure metamorphic rocks (jadeite-glaucophane-quartz rocks) based on the K-Ar dating is $124 \pm 2$ million years and $119 \pm 2$ million years (Parkinson et al., 1998). Based on $\mathrm{Rb}-\mathrm{Sr}$ dating, the age of metamorphic rocks, i.e., amphibious epidote in Luk Ulo, is 119-117 million years old (Hoffmann et al., 2019). Ultramafic rocks (basalt and diabase) based on K-Ar dating are $81 \pm 4.06$ million years old and $85.03 \pm 4.25$ million years old (Suparka, 1988). This group of diverse rocks in morphology is known as The Melange Seboro Complex. The hill's shape, the slope of the rocks, the north-south spread pattern, and the rocks' variation indicate that the Seboro melange complex is a group of rocks with exotic blocks (Asikin, 1974) and formed in the burial melange accretion zone (Prsetyadi, 2007).

Morphology in the middle area is a strong undulating landscape - hills that include structural geomorphological unit S13.7 (Ansori et al., 2020). This landscape is characterized by stepping slopes, land used as raindrop rice fields, found a large block of diabase around rice fields. Lithology is composed of clay breccia with fragments of claystone, sandstone, pillow lava, conglomerates, limestone nummulites with scaly clay matrix. The layering of rocks is generally chaotic with slump structures, but some indicate the development of layers. Totogan Formation sediment resulting from heavy force (olistostrome) (Asikin, 1974). At the same time, the valley floor of the Luk Ulo River is an elongated fault. Luk Ulo river is the largest watershed in Kebumen, with a winding shape due to the river's meandering process on the pre-tertiary rock.

Southern morphology is a hill that stretched eastwards in the form of a series of Paras Mts. and Prahu Mts as a synclinal ridge and includes geomorphological units S9.1 (Ansori et al., 2020). This morphology is characterized by regular hill and mountain forms with the flat hill, steep slopes, moderate-weak erosion. At the bottom of the hill are found boulders of andesite rocks that are fragments of breccia. The constituent rocks are volcanic breccia with layer sandstone that include the early Miosen of the Waturanda Formation (Asikin, 1974). Various types of rocks with a morphological appearance that make the place a natural textbook where the concept of plate tectonics can be studied and proven to be true (Ansori, C., Kumoro Y., Hastria D., 2016).

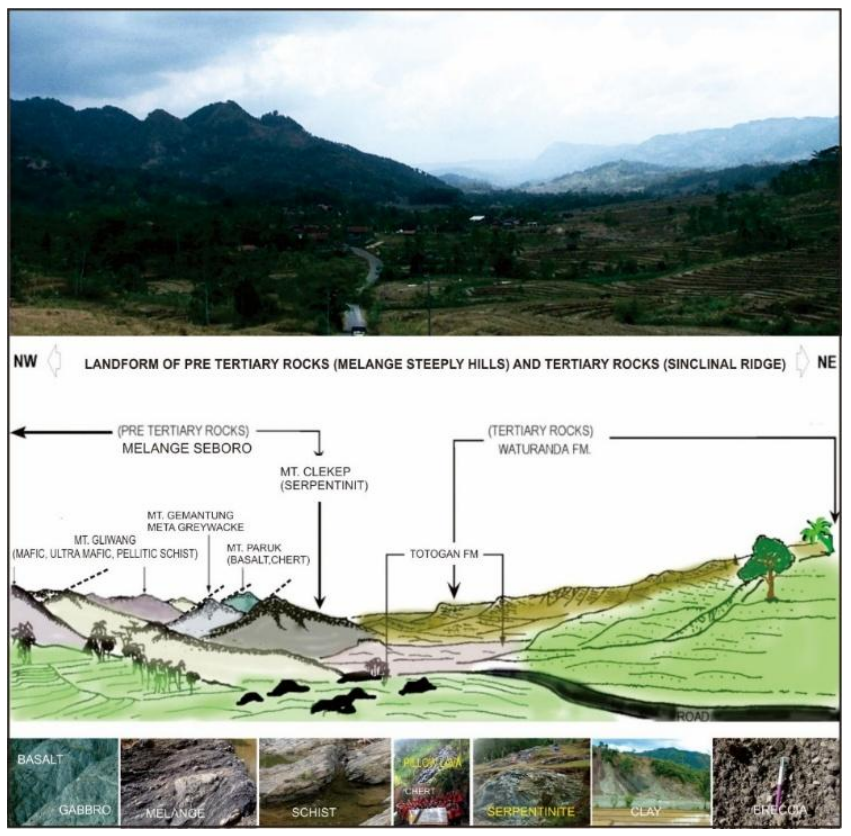

Fig 5. Sketch of the landscape as seen from Bukit Pentulu Indah, the hilly landscape of Mélange Seboro, the undulating morphology of strongstructural hills filled with deposits of Totogan Fm as olistostrome, and syncline ridge morphology on the volcanic breccia of Waturanda Fm.

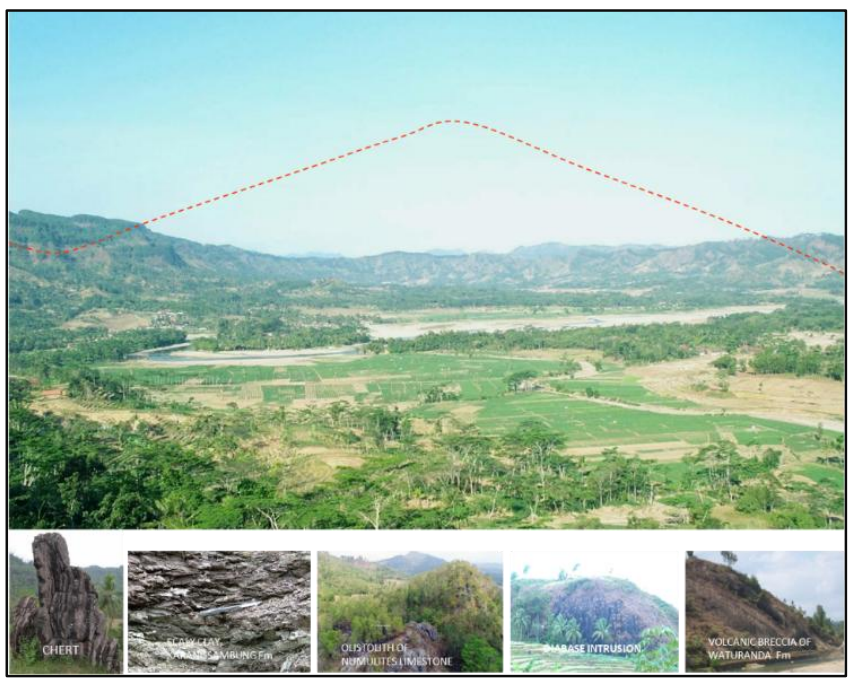

Fig 6. Anticline mountain landscape, syncline ridges, pediment, and alluvial plains that form an amphitheater due to a topographical reversal process where the anticline peaks turn into valleys and various rocks are encountered 


\subsubsection{Geomorphosite Wagirsambeng}

Wagirsambeng Hill is one of the isolated hills located in Karanggayam District. This hill is composed of deep-sea sedimentary rocks, namely chert and red limestone. This rock is located on the top of the hill leaving unique shapes resembling layer cake. This rock is very artistic and natural, with a height of about 4 meters is a very interesting shape. A chert sample (R55474) from Wagirsambeng contains middle Cretaceous radiolarians such as C. sphaerica (White), Spongocapsula sp., Novixitus sp. and Alievium sp. (Wakita, Munasri and Bambang, 1994). From all radiolarian data in this area, the Luk-Ulo Melange Complex is considered to have been deposited in Early to Late Cretaceous time and accreted at a subduction trench during the middle to the latest Cretaceous or earliest Paleocene. This complex is unconformably overlain by the Eocene (Wakita, Munasri and Bambang, 1994).

If the view is directed eastwards, there will be a landscape in the form of a valley extending west-east with a series of circular mountains around it in the form of horseshoes. In the southern part of the series Brujul Mt, Waturanda Mt, Dliwang Mt turns in Bukit Banda Hill. The northern series is Perahu Mt and Paras Mt. This kind of landscape is often referred to as the Amphitheater, a geomorphological unit of the anticline mountains S9.2 (Ansori et al., 2020). This valley is a former fold formed in Karangsambung but experienced a topographical reversal process; the anticline peak turned into a valley. The syncline valley turned into a synclinal ridge unit S9.1 (Ansori et al., 2020). The former anticline peaks are experiencing weathering, erosion, and avalanche processes. It turns into a valley with the Welaran River as an anticline axis and is included in the pediment unit. Meanwhile, under a series of horseshoe-shaped mountains found strong corrugated morphology infiltrated by clay breccia of Totogan Fm, weak corrugated morphology composed by scaly clay of Karangsambung Fm, and alluvial plains where Luk Ulo River flows (Figure 6).

\subsection{Geosite Assessment}

Geomorphosite assessment in the research area uses the Kubalikova assessment method (Kubalíková, 2013). The result assessment parameters of the Pentulu Indah and Wagir Sambeng landscape geosite can be seen in Table 1. Based on the assessment and weighting, it can be seen that the total value for PI is 16.26 points $(87.83 \%)$ good levels, while Wagirsambeng by 10.5 points $(56.75 \%)$ with a fairly good level. Each assessment variable for PI is always greater than the landscape geosite Wagirsambeng. The scientific and intrinsic value of $\mathrm{PI}=4$, while Wagirsambeng $=3$. Educational value $P I$ $=4$, while Wagirsambeng $=2$. Economic value is still not satisfactory, but PI $=2$, while Wagirsambeng $=1.5$. In general, conservation value has been good because of the support of regulations; although it is still not fully adhered to, the value of $\mathrm{PI}=3.5$, while Wagirsambeng $=2.5$. Added value $\mathrm{PI}=2.75$ while Wagirsambeng $=1.5$. In general, the economic value needs to be improved, especially from local products and accessibility, besides the potential damage to the site and the value of beauty on the Wagirsambeng site. Wagirsambeng value is relatively lower because this site's location has not been managed adequately than PI sites that have had institutional managers for quite a long time.

Table 1. Assessment of geomorphosite based on Kubalicova method

\begin{tabular}{|c|c|c|c|c|c|}
\hline \multirow{2}{*}{ No } & \multirow{2}{*}{ Variabels } & \multirow{2}{*}{ Score } & \multirow{2}{*}{ Extention } & \multicolumn{2}{|c|}{ Geomorphosite } \\
\hline & & & & PI & Wagirsambeng \\
\hline A & Scientific and intrinsic values & & & & \\
\hline \multirow[t]{3}{*}{1} & integrity & 0 & totally destroyed site & & \\
\hline & & 0,5 & the disturbed site, but with visible abiotic features & & 0,5 \\
\hline & & 1 & a site without any destruction & 1 & \\
\hline \multirow[t]{3}{*}{2} & rarity & 0 & more than 5 sites & & \\
\hline & & 0,5 & $2-5$ similar sites & & 0,5 \\
\hline & & 1 & the only site within the area of interest & 1 & \\
\hline \multirow[t]{3}{*}{3} & diversity & 0 & only one visible feature/processes & & \\
\hline & & 0,5 & $2-4$ visible features/processes & & \\
\hline & & 1 & more than 5 visible features/processes & 1 & 1 \\
\hline \multirow[t]{3}{*}{4} & scientific knowledge & 0 & unknown site & & \\
\hline & & 0,5 & scientific papers on national level & & \\
\hline & & 1 & $\begin{array}{l}\text { high knowledge of the site, monographic studies } \\
\text { about the site }\end{array}$ & 1 & 1 \\
\hline B & Educational values & & & & \\
\hline \multirow{4}{*}{1} & & 0 & $\begin{array}{l}\text { low representativeness/clarity of the form and } \\
\text { process }\end{array}$ & & \\
\hline & $\begin{array}{l}\text { representativeness } \\
\text { visibility/clarity of the } \\
\text { features/processes }\end{array}$ & 0,5 & $\begin{array}{l}\text { medium representativeness, especially for } \\
\text { scientists }\end{array}$ & & 0,5 \\
\hline & & 1 & $\begin{array}{l}\text { high representativeness of the form and process, } \\
\text { also for the laic public }\end{array}$ & 1 & \\
\hline & & 0 & $\begin{array}{l}\text { very low exemplarity and pedagogical use of the } \\
\text { form } \\
\text { and process }\end{array}$ & & \\
\hline \multirow[t]{3}{*}{2} & exemplarity, pedagogical use & 0,5 & $\begin{array}{l}\text { existing exemplarity, but with limited } \\
\text { pedagogical use, }\end{array}$ & & 0,5 \\
\hline & & 1 & $\begin{array}{l}\text { high exemplarity and high potential for } \\
\text { pedagogical } \\
\text { goedidactics and geotourism }\end{array}$ & 1 & \\
\hline & & 0 & no products, & & \\
\hline \multirow[t]{3}{*}{3} & existing educational products & 0,5 & leaflets, maps, web pages & & 0,5 \\
\hline & & 1 & info panel, information at the site & 1 & \\
\hline & actual use of a site for educational & 0 & no educative use of the site, & & \\
\hline 4 & $\begin{array}{l}\text { purposes (excursions, guided } \\
\text { tours) }\end{array}$ & $\begin{array}{c}0,5 \\
1\end{array}$ & $\begin{array}{l}\text { site as a part of specialized excursions (students) } \\
\text { guided tours for public }\end{array}$ & 1 & 0,5 \\
\hline $\mathbf{C}$ & Economic Value & & & & \\
\hline 1 & accessibility & $\begin{array}{c}0 \\
0,5\end{array}$ & $\begin{array}{l}\text { more than } 1000 \mathrm{~m} \text { from the parking place, } \\
\text { less than } 1000 \mathrm{~m} \text { from the parking place, }\end{array}$ & 0,5 & 0,5 \\
\hline
\end{tabular}




\begin{tabular}{|c|c|c|c|c|c|}
\hline & & 1 & more than $1000 \mathrm{~m}$ from the stop of public transport & & \\
\hline & & 0 & $\begin{array}{l}\text { more than } 10 \mathrm{~km} \text { from the site existing tourist } \\
\text { facilities }\end{array}$ & & \\
\hline 2 & presence of tourist infrastructure & 0,5 & $5-10 \mathrm{~km}$ tourist facilities, & & \\
\hline & & 1 & less than $5 \mathrm{~km}$ tourist facilities & 1 & 1 \\
\hline & & 0 & no local products related to a site, & & 0 \\
\hline 3 & local products & 0,5 & some products & 0,5 & \\
\hline & & & emblematic site for some local products & & \\
\hline D & Conservation Value & & & & \\
\hline & & 0 & high both natural and atrophic risks & & \\
\hline 1 & actual threats and risks & 0,5 & existing risks that can disturb the site & & 0,5 \\
\hline & & 1 & low risks and almost no threats & 1 & \\
\hline & & 0 & high both natural and atrophic risks & & \\
\hline 2 & potential threats and risks & 0,5 & existing risks that can disturb the site & 0,5 & 0,5 \\
\hline & & 1 & low risks and almost no threats & & \\
\hline & & 0 & the continuing destruction of the site & & \\
\hline 3 & current status of a site & 0,5 & $\begin{array}{l}\text { the site destroyed, but now with management } \\
\text { measures to avoid the destruction, }\end{array}$ & & 0,5 \\
\hline & & 1 & no destruction & 1 & \\
\hline & & 0 & no legislative protection & & \\
\hline 4 & legislative protection & 0,5 & existing proposal for legislative protection & & \\
\hline & & 1 & $\begin{array}{l}\text { existing legislative protection (Natural monument, } \\
\text { Natural reservation...) }\end{array}$ & 1 & 1 \\
\hline D & Added Value & & & & \\
\hline & & 0 & no cultural features & & \\
\hline 1 & $\begin{array}{l}\text { cultural values: the presence of } \\
\text { historical/archaeological/religious }\end{array}$ & 0,5 & $\begin{array}{l}\text { existing cultural features but without strong } \\
\text { relation to abiotic features, }\end{array}$ & 0,5 & 0,5 \\
\hline & aspects related to the site & 1 & $\begin{array}{l}\text { existing cultural features with strong relations to } \\
\text { abiotic features }\end{array}$ & & \\
\hline & & 0 & not important & & \\
\hline 2 & ecological values & 0,5 & existing influence but not so important & & 0,5 \\
\hline & & 1 & $\begin{array}{l}\text { the important influence of the geomorphologic } \\
\text { feature on the ecologic feature }\end{array}$ & 1 & \\
\hline 3 & aesthetic values: & & & & \\
\hline & & 0 & One colour & & \\
\hline a & number of colours; & 0.25 & $2-3$ colours & & 0,25 \\
\hline & & 0,5 & more than 3 colour & 0,5 & \\
\hline & & 0 & only one pattern & & 0 \\
\hline b & structure of the space & 0,25 & two or three patterns clearly distinguishable & 0,25 & \\
\hline & & 0,5 & more than 3 structure & & \\
\hline & & 0 & none & & \\
\hline $\mathrm{c}$ & viewpoints & 0,25 & $1-2$ viewpoint & & 0,25 \\
\hline & & 0,5 & 3 and more view point & 0,5 & \\
\hline & & Tota & value & 16,25 & 10,5 \\
\hline & & Procer & ge $(\%)$ & 87,8378 & 56,7568 \\
\hline
\end{tabular}

\section{Conclusion}

Geological diversity is the uniqueness of geological components such as minerals, rocks, fossils, geological structures, and landscapes that become the intrinsic wealth of an area representing the picture of the area's geological evolution process. Geological heritage (geo-heritage) is a geological diversity with more value as a heritage because it becomes a record that has been or is happening on Earth because of its high scientific value, rare, unique, and beautiful used for research and earth education. Geological Sites (Geosite) is a geological heritage in a geopark with certain characteristics, both individual and multi-object, and is an integral part of an evolutionary story of forming a region. Geomorphosite is a landscape of scientific value that describes geology's process and evolution in a region and is part of its geological history. The value of beauty and geomorphosite economy is often utilized as a place of geotourism. In the northern area of GNKK, two ideal geomorphosites describe the landform and geological processes. PI geomorphosite, the differences between geomorphology in the cretaceous melange tectonic complex, sedimentary melange rock (olisthostrome), and normal sedimentary rocks of tertiary age (Miocene) can be studied.

Meanwhile, in the Wagirsambeng geomorphosite, the geological process of the anticline and syncline hill topography reversal was observed, which resulted in the amphitheater landform. Scoring is based on scientific and intrinsic value, educational value, economic value, conservation value, and added value so that PI has a good value (87.83\%) while Wagirsambeng has sufficient value $(56.75 \%)$. The striking difference in values is mainly due to differences in geosite management.

\section{Acknowledgments}

Thank you to the Head of Research \& Development Division For Earth conservation and Information LIPI and GNKK management, which allowed us to run this research.

\section{References}

Ansori, C., Kumoro Y., Hastria D., W. K. (2016) Panduan Geowisata, menelusuri jejak dinamika bumi pada rangkaian Pegunungan Serayu dan pantai selatan Jawa, LIPI Press Jakarta. LIPI Press.

Ansori, C. (2018) "Geosite identification in karangbolong high to support the development of karangsambungkarangbolong geopark candidate, central java," IOP Conference Series: Earth and Environmental Science, 118(1). doi: 10.1088/1755-1315/118/1/012014.

Ansori, C. et al. (2020) "Geomorphology and iron sand potential at coastal sediment morphology, Kebumen Regency," E3S Web of Conferences, 200. doi: 10.1051/e3sconf/202020006004.

Asikin, S. (1974) Evolusi geologi jawa tengah dan sekitarnya ditinjau dari segi tektonik dunia yang baru., ITB. 
Brilha, J. (2016) "Inventory and quantitative assessment of geosites and geodiversity sites: a review," Geoheritage. Geoheritage, 8(2), pp. 119-134. doi: 10.1007/s12371-0140139-3.

Brilha, J. (2018) "Geoheritage: Inventories and evaluation," Geoheritage: Assessment, Protection, and Management, pp. 69-85. doi: 10.1016/B978-0-12-809531-7.00004-6.

Bruschi, V. M. and Cendrero, A. (2005) "Geosite evaluation; can we measure intangible values?," Alpine and Mediterranean Quaternary, 18(1), pp. 293-306.

Carton, A., Cavallin, A. Francavilla, F., Mantovani, F., Panizza, M., Pellegrini, G. G. (1994) "Ricerche ambientali per l'individuazione e la valutazione dei beni geomorfologici metodi ed esempi. II."

GGN, G. (2021) Global geopark network. Available at: https://en.unesco.org/global-geoparks (Accessed: August 12, 2021).

Gordon, J.E., Barron, H. F. (2011) "Scotland's geodiversity: development of the basis for a national framework, scottish natural heritage," Scotland's geodiversity, (Scotland's geodiversity).

Gordon, J.E.; Crofts, R.; Diaz-Martinez.E; and Woo, K. S. (2017) "Enhancing the role of geoconservation in protected area management and nature conservation," Geoheritage. doi: 10.107/s123710-17-0240-5.

Gordon, J. E. (2012) "Rediscovering a sense of wonder: geoheritage, geotourism, and cultural landscape experiences," Geoheritage, 4-1, pp. 65-77.

Grandgirard, V. (1995) "M'ethode pour la r'ealisation d'un inventairre de g'eotopes g'eomorphologiques," in. UKPIK, Cahiers de l'Institut de G'eographie de l'Universit'e de Fribourg 10, pp. 121-137.

Grandgirard, V. (1999) “L'evaluation des g'eotopes," in Geol. Insubr 4 (1), pp. 66-69.

Gray, M. (2008) "Geodiversity: the origin and evolution of a paradigm," in Burek, C.D., Prosser, C. . (ed.) The History of Geoconservation. Special Publication 300. The Geological Society, London, pp. 31-36.

Gray, Murray (2013) "Geodiversity: valuing and conserving abiotic nature, 2nd edition," in Geodiversity. second edi. London: Wiley Blackwell, p. 512.

Gray, M. (2018) "Geodiversity: The backbone of geoheritage and geoconservation," Geoheritage: Assessment, Protection, and Management, pp. 13-25. doi: 10.1016/B978-0-12-809531-7.00001-0.

Hoffmann, J. et al. (2019) "Age constraints on highpressure/low-temperature metamorphism and sedimentation in the Luk Ulo Complex (Java, Indonesia)," Lithos. Elsevier B.V., 324-325, pp. 747-762. doi: 10.1016/j.lithos.2018.11.019.

Hooke, J. M. (1994) "Strategies for conserving and sustaining dynamic geomorphological sites," in O'Halloran, D., Green, C., Harley, M., Knill, J. (ed.) Geological and Landscape Conservation. Geological. The Geological Society, London, pp. 191-195.

Ketner, K. B. et al. (1976) "Pre-Eocene rocks of Java, Indonesia," Journal Research U.S. Geological Survey, 4(5), pp. 605-614.

Kubalíková, L. (2013) "Geomorphosite assessment for geotourism purposes," Czech Journal of Tourism, 2(2), pp. 80-104. doi: 10.2478/cjot-2013-0005.

Miyazaki, K. et al. (1998) "A jadeite-quartz-glaucophane rock from Karangsambung, central Java, Indonesia," Island Arc, $7(1-2)$, pp. 223-230. doi: 10.1046/j.14401738.1998.00164.x.

Newsome, D. \& Dowling, R. K. (2010) Geotourism: the tourism of geology and landscape. doi: 10.23912/978-1906884-09-3-21.
Panizza, M., Piacente, S. (1993) "Geomorphological assets evaluation," Zeitschr. fur Geomorphologie, 87, pp. 13-18.

Panizza, M., Piacente, S. (2009) "Cultural geomorphology and geodiversity," in Reynard, E., Coratza, P., Regolini-Bissig, G. (ed.) Geomorphosites, pp. 35-48.

Panizza, M. (2001) "Geomorphosites: concepts, methods, and examples of the geomorphological survey," Chinese Science Bulletin, 46-1, pp. 4-5. Available at: https://doi.org/10.1007/BF03187227.

Paola Coratza, and F. H. ea (2018) "The Specificities of geomorphological Heritage," in Reynard E, B. J. (ed.) Geoheritage, Assessment, Protection and Management. Elsevier.

Parkinson, C. D. et al. (1998) "An overview and tectonic synthesis of the pre-Tertiary very-high-pressure metamorphic and associated rocks of Java, Sulawesi and Kalimantan, Indonesia," Island Arc, 7(1-2), pp. 184-200. doi: 10.1046/j.1440-1738.1998.00184.x.

Perpres, P. (2019) Perpres 9/2019, Pengembangan Taman Bumi(Geopark).

Pralong, J. P. (2005) "A method for assessing tourist potential and use of geomorphological sites," Géomorphologie: Relief, Processus, Environnement, 11(3), pp. 189-196.

Prsetyadi, C. (2007) Evolusi Tektonik Paleogen Jawa Bagian Timur. ITB.

Quaranta, G. (1993) “Geomorphological assets: conceptual aspect and application in the area of Croda da Lago," in Panizza, M., Soldati, M., Barani, D. (ed.) European Intensive Course on Applied Geomorphology Proceedings, pp. 46-60.

Reynard, E. (2005) "G'eomorphosites et paysages G'eomorphol," Relief Proces. Environ, 3, pp. 181-188.

Reynard, E. and Coratza, P. (2007) "Geomorphosites and geodiversity: A new domain of research," Geographica Helvetica, 62(3), pp. 138-139. doi: 10.5194/gh-62-1382007.

Reynard, E. and Coratza, P. (2016) "The importance of mountain geomorphosites for environmental education: examples from the italian dolomites and the swiss alps," Acta geographica Slovenica, 56(2). doi: 10.3986/1684.

Reynard, E. and Giusti, C. (2017) "The landscape and the cultural value of geoheritage," in Geoheritage: Assessment, Protection, and Management. Elsevier Inc., pp. 147-166. doi: 10.1016/B978-0-12-809531-7.00008-3.

Rivas, V., Rix, K., Frances, A. and Cendrero, A., Brunsden, D. (1997) "Geomorphological indicators for environmental impact assessment: consumable and non-consumable geomorphological resources," Geomorphology, 18, pp. 169-182.

Serrano, E. and González-Trueba, J. J. (2005) “Assessment of geomorphosites in natural protected areas: the Picos de Europa National Park (Spain)Évaluation des géomorphosites dans les espaces naturels protégés: le Parc National des Picos de Europa (Espagne)," Géomorphologie : relief, processus, environnement, 11(3), pp. 197-208. doi: 10.4000/geomorphologie.364.

Suparka, E. (1988) Studi Petrologi dan Pola Kimia Kompleks Ofiolit Karangsambung Utara Luh Ulo, Jawa Tengah. ITB.

UNESCO, U. (2016) Operational guidelines for the implementation of the world heritage convention. Available at: http://whc.unesco.org/en/guidelines.

Wakita, K., Munasri and Bambang, W. (1994) "Cretaceous radiolarians from the Luk-Ulo Melange Complex in the Karangsambung area, central Java, Indonesia," Journal of Southeast Asian Earth Sciences, 9(1-2), pp. 29-43. doi: 10.1016/0743-9547(94)90063-9.

Zouros, N. (2005) "Assessment, protection, and promotion of geomorphological and geological sites in the Aegean area, 
GreeceÉvaluation, protection et promotion des sites géomorphologiques et géologiques de la région égéenne, Grèce," Géomorphologie: relief, processus, environnement, 11(3), pp. 227-234. doi: 10.4000/geomorphologie.398. (c) () (2) (C) 2021 Journal of Geoscience, Engineering, (C) Environment and Technology. All rights reserved. This EY SA is an open access article distributed under the terms of the CC BY-SA License (http://creativecommons.org/licenses/by-sa/4.0/). 